Quille M.E. and O'Kelly B.C., Geotechnical properties of zinc/lead mine tailings from

Tara Mines, Ireland, Proceedings ASCE GeoShanghai 2010 Geoenvironmental

Engineering and Geotechnics: Progress in Modeling and Applications, Shanghai, China, 3rd-5th June, Q. He and S-L. Shen, GSP 204, 2010, 111 - 117

\title{
Geotechnical properties of zinc/lead mine tailings from Tara Mines, Ireland
}

\author{
Michael E. Quille ${ }^{1}$ and Brendan C. O’Kelly ${ }^{2}$ \\ ${ }^{1}$ Research Assistant, Department of Civil, Structural and Environmental Engineering, Trinity College \\ Dublin, Ireland; quillem@tcd.ie \\ ${ }^{2}$ Lecturer, Department of Civil, Structural and Environmental Engineering, Trinity College Dublin, Ireland; \\ bokelly@tcd.ie
}

ABSTRACT: This paper presents the geotechnical properties of the zinc/lead mine tailings from Tara Mines in County Meath, Ireland. The coarser and finer materials from the mechanical crushing and grinding processes were classified as slightly sandy silt and clayey silt, with high specific gravity of solids values of 2.78 and 2.82 , and bulk density values of 2.01 and 2.08 tonne $/ \mathrm{m}^{3}$, respectively. Chemical analysis indicated that the tailings comprised high proportions of calcium and magnesium (derived from the limestone ore body), with high residual concentrations of zinc and lead. The materials in the tailings pond were in a loose to medium dense state, with low to very low hydraulic conductivity of the order of $10^{-6}-10^{-8} \mathrm{~m} / \mathrm{s}$, and values of effective angle of shearing resistance of $37^{\circ}$ (coarse) and $32^{\circ}$ (fine). An indicative inert capping layer is presented that will form part of the rehabilitation works towards reintegrating the tailings pond into the surrounding landscape when its storage capacity is reached.

\section{INTRODUCTION}

Mine tailings consist of the pulverized rock that remains after the mechanical and chemical processes that are used to extract the metal ores from the ore body. The disposal and management of tailings storage facilities are fundamental concerns for the mining industry, owing to the large volume and chemical composition of these spoil materials. At present, most tailings are retained in slurry form behind dams, embankments or other surface impoundments. Tailings disposal is subject to stringent regulations (e.g. European Union Directive on the Management of Waste from Extractive Industries, 2006) in order to prevent environmental impacts that include, for example, the leaching of heavy metal pollutants into surrounding watercourses.

Tara Mines is operated by the New Boliden Group and is currently one of the largest zinc mines in Europe, and the fifth largest in the world, producing about 2.7 million 
tonnes of zinc and lead concentrates annually. The ores are extracted from the limestone rock using the mechanical and chemical processes of crushing and grinding; froth floatation; dewatering; and cycloning (Vick, 1990). The mechanical crushing and grinding processes generate two material types that are distinguished by their particle size distribution, namely coarser and finer tailings. At Tara Mines, about half of the coarser tailings are separated by cycloning; mixed with cement at a ratio of 15:1 to 30:1; and used as mine stope backfill. The remaining tailings are mixed with the process wastewater and pumped about $5 \mathrm{~km}$ to the Randalstown tailings impoundment, where they are discharged into the tailings beaches, via a series of $200 \mathrm{~mm}$ spigots, located at 80 $\mathrm{m}$ intervals around the perimeter of the earthfill dams. The tailings pond covers an area of about 160 ha and the earthfill dams are up to $12.5 \mathrm{~m}$ high, with side slopes of one vertical to two horizontal. The hydraulic deposition process produces heterogeneous tailings deposits, with the denser particles settling out first. Water ponded over the tailings surface prevents wind erosion of the tailings dust. Groundwater from the tailings pond is controlled by a horizontal seepage system, and along with the supernatant water, is collected and re-circulated back to the mine, where it is reused in the ore extraction process.

The geotechnical properties of the mine tailings must be understood in order to construct more environmentally-friendly tailing ponds, and to further improve the efficiency of these disposal methods. In this paper, the geotechnical properties of the coarser and finer tailings from the tailings ponds at Tara Mines were studied, along with the development of an indicative inert capping layer that will form part of the rehabilitation works towards reintegrating the tailings pond into the surrounding landscape.

\section{GEOTECHNICAL PROPERTIES}

Bulk tailing samples were sourced from shallow depths at the Randalstown tailings impoundment and stored, prior to testing, in plastic drums at ambient laboratory temperature. The geotechnical properties were determined using standard laboratory tests to BS 1377 (1990).

\section{INDEX AND PHYSIOCHEMICAL PROPERTIES}

Table 1 lists some index and physical properties of the grayish-black tailings.

Table 1. Index and physical properties of the mine tailings.

\begin{tabular}{|lll|lll|}
\hline Parameter & Coarse & Fine & Parameter & Coarse & Fine \\
\hline Liquid limit $(\%)$ & - & 75 & Max void ratio & 0.71 & 0.64 \\
Plastic limit $(\%)$ & - & 60 & Min void ratio & 0.47 & 0.43 \\
Effective size, $\mathrm{D}_{10}(\mathrm{~mm})$ & 0.008 & $<0.002$ & Bulk density $\left(\right.$ tonne $\left./ \mathrm{m}^{3}\right)$ & 2.01 & 2.08 \\
Specific gravity of solids & 2.78 & 2.82 & Dry density $\left(\right.$ tonne $\left./ \mathrm{m}^{3}\right)$ & 1.78 & 1.83 \\
Insitu water content $(\%)$ & 15 & 20 & Max dry unit weight $\left(\right.$ tonne $\left./ \mathrm{m}^{3}\right)$ & 1.89 & 1.97 \\
Insitu void ratio & 0.63 & 0.61 & Min dry unit weight $\left(\right.$ tonne $\left./ \mathrm{m}^{3}\right)$ & 1.62 & 1.71 \\
\hline
\end{tabular}


Figure 1 shows the particle size distribution of the materials that were determined from a wet-sieve analysis. The coarser and finer tailings were classified as slightly sandy silt and clayey silt, respectively. The finer tailings had a liquid limit value of $75 \%$ (measured using the fall-cone penetrometer method); a plastic limit value of $60 \%$; and hence a plasticity index value of 15 . The specific gravity of solids was determined using the glass jar method, with high values of 2.78 (coarse) and 2.82 (fine). High concentrations of residual zinc and lead are generally contained in the finer tailings (Vick, 1990), which accounts for its slightly higher specific gravity of solids value. Values of bulk density of 2.01-2.08 tonnes $/ \mathrm{m}^{3}$ and dry density of $1.78-1.83$ tonnes $/ \mathrm{m}^{3}$ were measured over the water content range $6 \%-30 \%$.

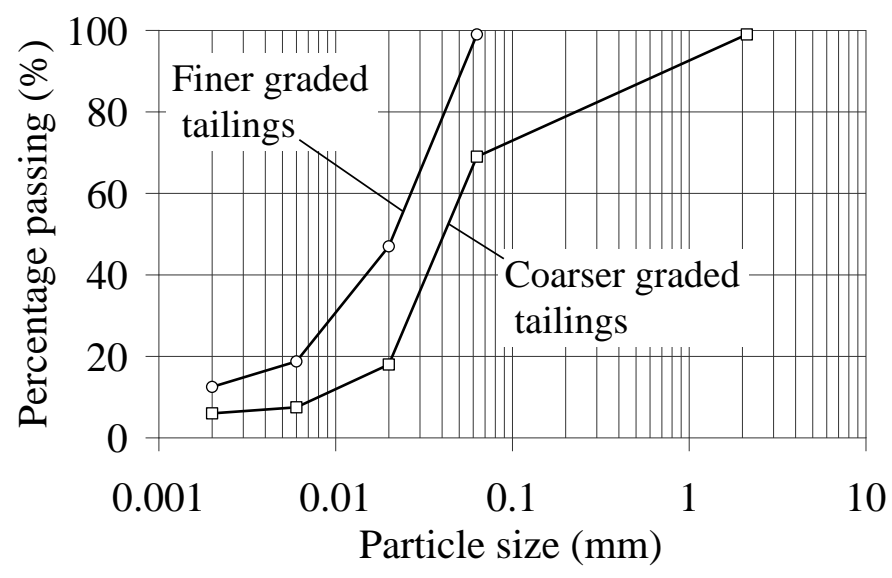

FIG. 1. Particle size distribution of the tailings.

\section{CHEMICAL PROPERTIES}

The chemical composition of the tailings reflects the chemistry of the ore body, the ore mineralogy and the metallurgical processes. The tailings were slightly alkaline and comprised high proportions of calcium and magnesium, which were derived from the limestone ore body, along with high residual concentrations of zinc and lead (Table 2).

Table 2. Chemical composition of the tailings.

\begin{tabular}{|l|l|l|l|l|l|l|l|}
\hline Parameter & Range & Parameter & Range & Parameter & Range & Parameter & Range \\
\hline $\mathrm{pH}$ & $7.0-7.9$ & Mercury & $<0.5-0.9$ & Chromium & $40-310$ & Sulfide & $3.0 \%-5.5 \%$ \\
Aluminum & $445-11488$ & Molybdenum & $<25$ & Cobalt & $15-26$ & Tellurium & $<5-7$ \\
Arsenic & $90-600$ & Nickel & $47-100$ & Copper & $30-171$ & Thallium & $17-43$ \\
Barium & $118-288$ & Potassium & $333-10000$ & Iron & $26.0-69.5$ & Tin & $<5-212$ \\
Boron & $<5-16$ & Silver & $<5-18$ & Lead & $1.4-2.9$ & Titanium & $5-900$ \\
Cadmium & $12.5-39.1$ & Sodium & $647-1100$ & Magnesium & $11.5-73.0$ & Uranium & $<5$ \\
Calcium & $22 \%-44 \%$ & Sulfate & $0.19 \%-6.59 \%$ & Manganese & $1.4-2.3$ & Zinc & $3912-11169$ \\
\hline
\end{tabular}

Note: Values are given in $\mathrm{mg} / \mathrm{kg}$ (i.e. parts per million) dry mass basis, unless otherwise stated. Data are mean values for coarser and finer tailings (Tara Mines Ltd., 1995). 


\section{SHEAR STRENGTH \\ TRIAXIAL COMPRESSION}

Quick-undrained triaxial compression tests were conducted on standard Proctor compacted specimens, $100 \mathrm{~mm}$ in diameter and $200 \mathrm{~mm}$ high, over the water content range $6 \%-20 \%$. A cell confining pressure of $100 \mathrm{kPa}$ was applied to the triaxial specimens, which were sheared quickly at a rate of $2 \%$ axial strain/min. Figure 2 shows data for the deviator stress against axial strain.

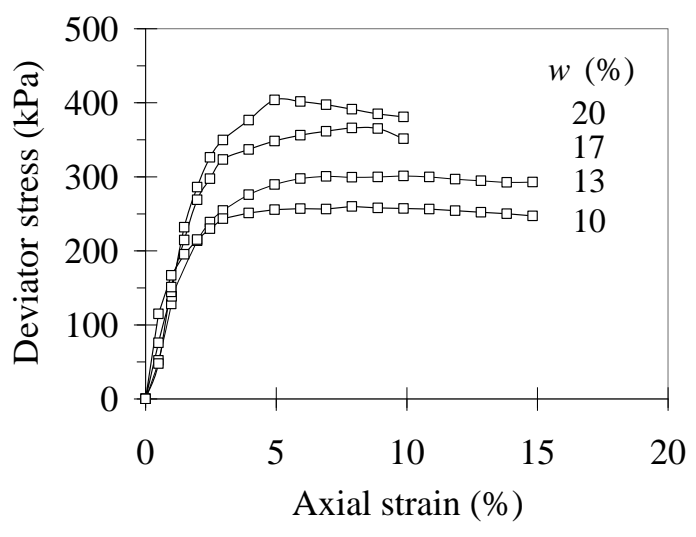

(a) Coarser tailings.

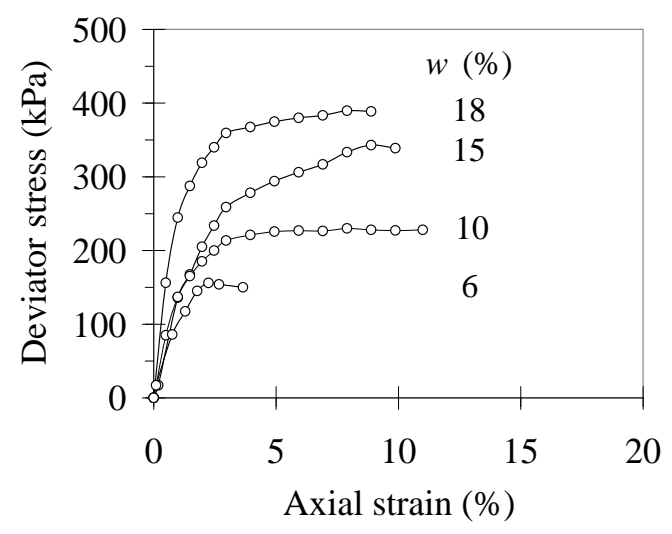

(b) Finer tailings.

FIG. 2. Deviator stress against strain data ( $w$, water content).

\section{SHEARBOX}

Shearbox tests were conducted on saturated specimens, $60 \mathrm{~mm}$ square by $20 \mathrm{~mm}$ deep, which were sheared at a rate of $0.6 \mathrm{~mm} / \mathrm{min}$; sufficiently slow to allow full dissipation of the pore water pressures to occur throughout the specimens under the applied normal stresses of 50, 100 and $200 \mathrm{kPa}$ (Figs. 3 and 4). The values of effective angle of shearing resistance of $37^{\circ}$ (coarse) and $32^{\circ}$ (fine) were determined from the data of shear stress at failure against normal stress (Fig. 5). As expected, the coarser tailings gave higher shear stress values at similar applied normal stresses, and hence a higher effective angle of shearing resistance value.

\section{HYDRAULIC CONDUCTIVITY}

The hydraulic conductivity was determined using falling-head permeability tests to BS 1377 (1990). The tailings specimens, $100 \mathrm{~mm}$ in diameter and $160 \mathrm{~mm}$ high, were loosely poured into the permeameter, with typical values of relative density of 0.33 (coarse) and 0.18 (fine), simulating insitu conditions. Values of hydraulic conductivity of $6.0 \times 10^{-6}$ $\mathrm{m} / \mathrm{s}$ (coarse) and $2.0 \times 10^{-8} \mathrm{~m} / \mathrm{s}$ (fine) were measured at ambient laboratory temperature of $20^{\circ} \mathrm{C}$. 


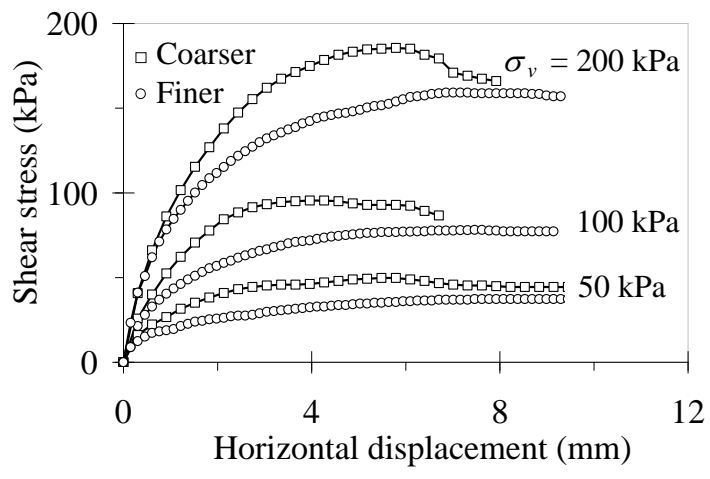

FIG. 3. Shear stress against horizontal displacement.

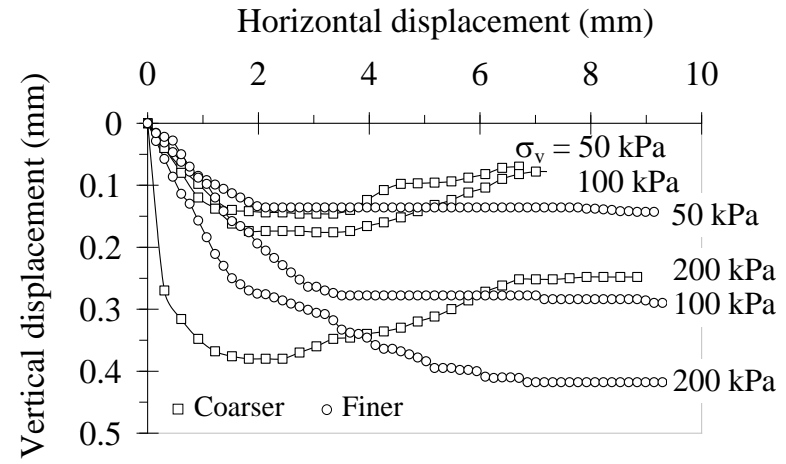

FIG. 4. Vertical displacement against horizontal displacement.

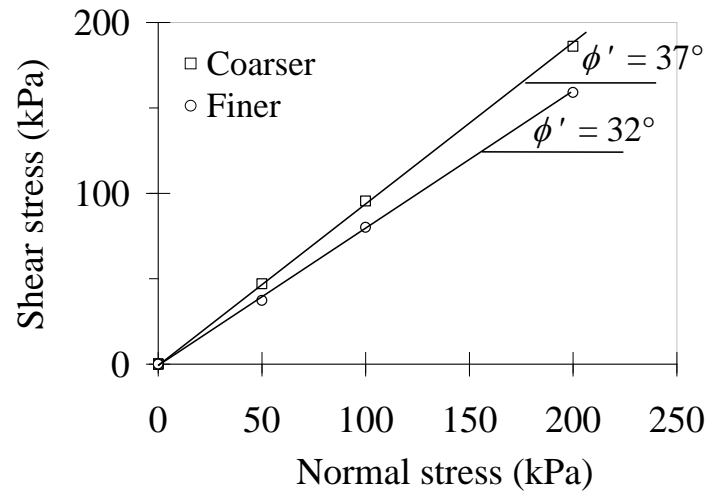

FIG. 5. Shear stress against normal stress ( $\phi^{\prime}$, effective angle of shearing resistance).

\section{COMPRESSION}

The compression behavior was determined using oedometer tests, with two-way specimen drainage to atmosphere, over the applied stress range $6-400 \mathrm{kPa}$. The test specimens, $76.2 \mathrm{~mm}$ in diameter and $18 \mathrm{~mm}$ high, were taken direct from the tailings pond, simulating insitu conditions. The coarser and finer tailings consolidated quickly, 
although with small load strains of 3\%-9\% measured under the final compression stage at $400 \mathrm{kPa}$. Figure 6 shows the data of void ratio against effective stress, with a compression index value of only 0.09 for the finer tailings, determined from the gradient of its $e-\log$ $\sigma_{v}{ }^{\prime}$ curve.

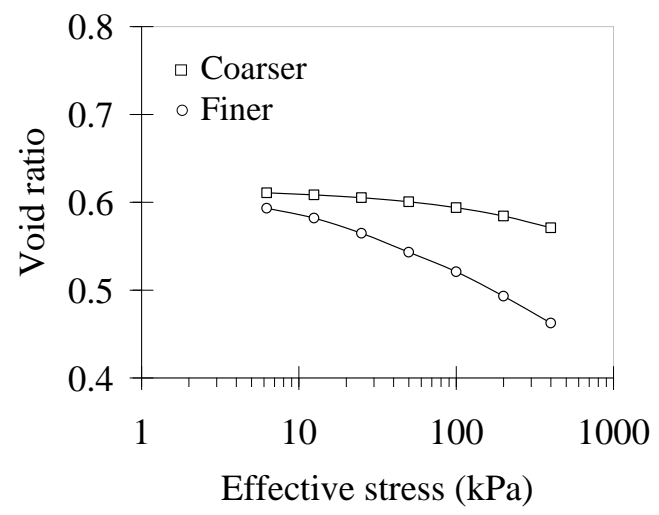

FIG. 6. Void ratio against effective stress.

\section{CAPPING LAYER}

An inert capping layer, comprising topsoil; subsoil; Terram non-woven geotextile; and inert rockfill layer; will be constructed above the tailings pond at full height (Fig. 7), in order to encourage the growth of vegetation and to reintegrate the tailings pond into the surrounding landscape. The geotextile layer will prevent the upward migration of fines from the tailings pond into the capping subsoil and topsoil layers, while the inert rockfill will act as a drainage layer, and will also serve as a working platform to facilitate the capping layer construction.

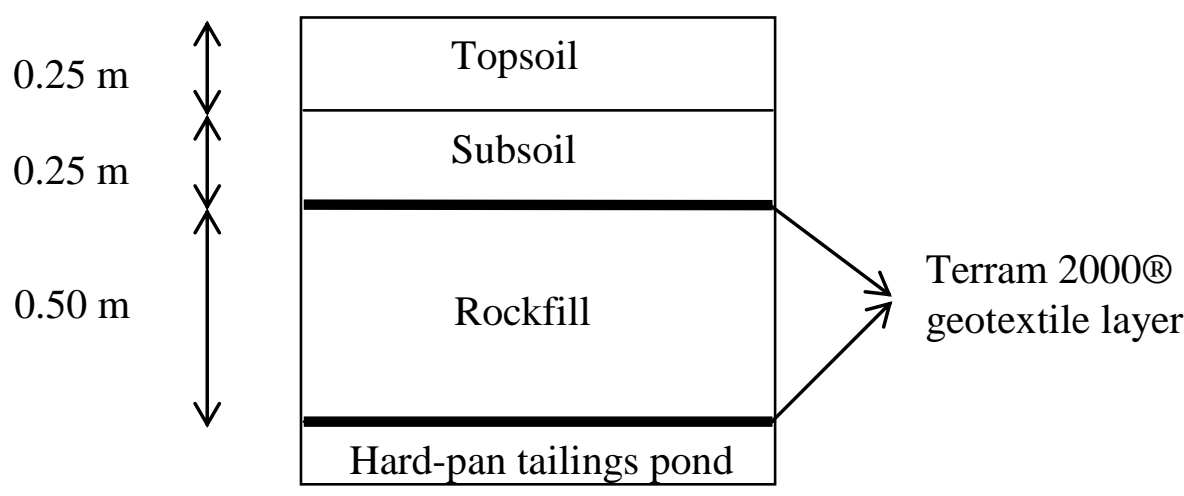

FIG. 7. Proposed capping layer with indicative dimensions.

\section{SUMMARY AND CONCLUSIONS}

The coarser and finer tailings from Tara Mines were classified as slightly sandy silt and clayey silt respectively, and contained high proportions of calcium and magnesium from the limestone ore body, with specific gravity of solids of 2.78 (coarse) and 2.82 (fine). 
The higher value of the latter was due to its higher concentration of residual zinc and lead. The values of bulk and dry density were high, although in line with the high values of specific gravity of solids. The values of effective angle of shearing resistance were $37^{\circ}$ (coarse) and $32^{\circ}$ (fine), with values of hydraulic conductivity for the coarse and fine tailings in the loose to medium dense state of $6.0 \times 10^{-6} \mathrm{~m} / \mathrm{s}$ and $2.0 \times 10^{-8} \mathrm{~m} / \mathrm{s}$, respectively. The tailings consolidated quickly, with small cumulative strains of $3 \%-9 \%$ measured during the oedometer tests under applied stresses of up to $400 \mathrm{kPa}$. An indicative inert capping layer was presented that will form part of the rehabilitation works towards reintegrating the tailings pond into the surrounding landscape.

\section{ACKNOWLEDGMENTS}

The authors acknowledge the work of Martin Carney and Aaron Kelly in performing some of the tests on the tailings materials at the geotechnical laboratory, Trinity College Dublin. In addition, the authors would like to thank the Environmental Department at New Boliden Tara Mines for their assistance during this study. Michael Quille would like to acknowledge funding received through postgraduate research awards from Trinity College Dublin and the Geotechnical Trust Fund of Engineers Ireland.

\section{REFERENCES}

BS 1377 (1990). "Methods of Test for Soils for Civil Engineering Purposes." British Standards Institution, London.

Council of the European Union (2006). "The Management of Waste from Extractive Industries." Official Journal of the European Communities, L3102/15: 1-19.

Tara Mines Ltd. (1995). "Environmental Impact Statement." Tara Mines Publications, Navan, Ireland.

Vick, S.G. (1990). "Planning, Design, and Analysis of Tailings Dams." BiTech Publishers, Vancouver. 